\title{
Management of Dual Health Asset Applications Developed by The Ministry of Internal Affairs and Ministry of Health in Hospitals in Boyolali, Central Java, Indonesia
}

\author{
Yunita Rusdiyanti'), Didik Gunawan Tamtomo²), Bhisma Murti1) \\ 1)Masters Program in Public Health, Universitas Sebelas Maret \\ 2)Faculty of Medicine, Universitas Sebelas Maret
}

\section{ABSTRACT}

Background: The management of health assets in Hospitals is a complex matter. Stateonwed Hospitals use two applications from the Ministry of Internal Affairs developed by the Development Audit Agencynamely Regional Management Information System of Regional Assets (Simda BMD) and the Ministry of Health namely Application of Infrastructure and Medical Devices (ASPAK). This study aims to determine the management of health assets based on the applications of the Ministry of Internal Affairs and the Ministry of Health in three Regional Public Hospitals in Boyolali Regency.

Subjects and Method: This was a descriptive-qualitative study using a study case approach. This study was carried out in three Regional Public Hospitals in Boyolali Regency. The main informants were goods treasurer, warehouse section, staff in charge of planning and reporting section, staff in charge of ASPAK, head of medical support, and head of administrative subdivision. The data were collected using in-depth interviews, non-participative observation, and document observation. The data were analyzed using three main steps namely data reduction, data display, and conclusion drawing.

Results: The staff in charge of asset management in RSUD Boyolali had a sufficient proficiency in the asset concept and management by using the two applications. However, not all steps were conducted on time andfollowing the guidance.

Conclusion: The training is required to improve the capability of the staff in charge of asset management. A system is also required to link the two applications to provide more efficient input system and create inter operability.

Keywords: asset management

\section{Correspondence:}

Yunita Rusdiyanti. Masters Program in Public Health, Universitas Sebelas Maret. Jl. Ir. Sutami 36A, Surakarta 57126, Central Java. Email: y_rusdiyanti@yahoo.com. Mobile: 08122981365 .

\section{Cite this as:}

Rusdiyanti Y, Tamtomo DG, Murti B (2020). Management of Dual Health Asset Applications Developed by The Ministry of Internal Affairs and Ministry of Health in Hospitals in Boyolali, Central Java, Indonesia. J Health Policy Manage. 05(03): 189-196. https://doi.org/10.26911/thejhpm.2020.05.03.04.

(c) (F) (-) Journal of Health Policy and Management is licensed under a Creative Commons Attribution-NonCommercial-ShareAlike 4.0 International License.

\section{BACKGROUND}

Health is the part of the economic and social development of a countrythus each country provides affordable and quaility health service facilities for all levels of society (WHO, 2018). Everyone has the right to obtain quality and affordable health services. This can be achieved when there are easy access to health services, the implementation of health services by competent and compliant officers, the guarantee availability of infrastructure and medical supplies andsafe and usable medical support equipment, and the availability of adequate pharmaceutical supplies (Hidayati, 2014). 
Besides ensuring safe and quality service, the availability of infrastructure and medical equipment also decreases unnecessary referral rates. The stakeholders require data access and information to understand and conduct supervision and control toward health service facilities. Therefore, adequate infrastructure is required. Infrastructure is the fundamental part to support optimal care by preventing infections and decreasing referral rates. The use of health applications is a means to support optimal health by maintaining data accuracy (Bryant et al., 2016).

Government Regulation of the Republic of Indonesia Number 27 the year 2014 about state property asset management declared that an asset of the State is anything purchased or funded through the State budgeting while a regional asset is anything funded or purchased through its respective regional budgeting. The policy of regional autonomy furthermore provides an impact for a particular region to occupy its governmental and social demand through the aspiration of the society because the region hasthe obligation, authority, and right as the autonomous region. A centralized government system is now replaced into a decentralized system for regional development (Anton, 2017).

A study related to the assets management and asset utilization is one form of evaluation that can be carried out to improve the service of good asset management. Based on the study conducted by Harmein (2015), there werethree variables affect assets optimization andhad not been performed according to standard namely assets inventory, legal audit, and asset valuation. A study conducted by Permatasari (2014)also argued that assets management in web applicationshad not been optimal due to the lack of maintenance and competent human resource in assets management. The assets require high operation and maintenance costs however it cannot be used thereforeit is inefficient.

Based on the explanation, the authors are interested in conducting a study related to the management of health asset based on the application developed bythe Ministry of Home Affairs and Ministry of Health in three Regional Public Hospitals in Boyolali Regency.

\section{SUBJECTS AND METHOD}

\section{Design of The Study}

This was a descriptive qualitative study using a case study approach. This study was carried out at three Regional Public Hospitals in Boyolali Regency from May to June 2019.

\section{Informants}

The informants in this study were ten informants including staff of Regional Public Hospital (RSUD) Waras Wiris from planning and reporting section, treasurer and electromedical engineering/Installation Maintenance Infrastructure Hospital (IPSRS), goods treasurer, Head of Medical Support Section. The staff of Regional Public Hospital Pandanarang who responsible for the Application of Infrastructure and Medical Devices (ASPAK)/ Electromedical/ Installation Maintenance Infrastructure Hospital (IPSRS),goods treasurer, and warehouse section. The staff of RSUD Simo came from goods treasurer, warehouse section, Head of Administration Subdivision. The samples were choosen using purposive sampling techniques

\section{Data Collection}

This study used in-depth interviews, nonparticipatory observation, and document observation as data collecting techniques. The data collecting tools of this study were interview guidelines, recorder, stationery, laptop, and camera. The data were analyzed using three main steps namely data 
reduction, data display, and conclusion drawing.

\section{Data Analysis}

This study used three main steps to analyze the data namely data reduction, data display, and conclusion.

\section{Research Ethics}

The research ethics of this study were based on informed consent, anonymity, confidentiality, ethical clearance. The Ethical clearance in this study was conducted at Dr. Moewardi Hospital Number: 743/VI/HREC/2020.

\section{DISCUSSION}

This study was carried out using in-depth interviews with the main informants to identify the hospital asset management such as input data, Simda and ASPAK socialization, dan the role of Regional Financial Board (BKD). This study was conducted in three Regional Public Hospitals (RSUD) in Boyolali Regency for 30 days from May to June 2019. The total subjects of this study were ten staff responsible for Hospital asset management.

All the informants of this study realized that the two applications were very helpful in assets management, especially when the data input and monitoring were carried out routinely. The obstacles were the menu that changed frequently without socialization and inadequate training. The data input was performed twice separately and had not synchronized yet between the two applications so that it was inefficient.

The result of the in-depth interview related to the time of data input implied that there were different times of the data input among the three hospitals. In RSUD Pandanarang the data input was performed when there was a new asset addition. In RSUD Simo and Waras Wiris the data input was carried out at the end of the year for Regional Management Information System (simda BMD) after the financial close processes in the current year and simda finance had finished. The input of the application of Infrastructure and Medical Devices (ASPAK) was carried out at the beginning of the following year beforethe financial plan of the Special Allocation Fund (DAK).

"The data input in the applications especially ASPAK was conducted when there was a new asset addition or asset decrement" (DAP, 44 years, staff in charge of ASPAK of Pandanarang hospital).

The statement is in line with the statement from another informant:

"The data input in simda BMD was carriedout atthe end of the year when the simda finance had finished. It was synchronized with the input of asset addition. The data input in ASPAK was conducted at the beginning of the following year before the financial plan of DAK". (M, 33 years, staff in charge of planning and report section of Waras Wiris hospital).

All the staff in charge had already understood about the steps and the input method in simda BMD and ASPAK. Although there was minimum training from Regional Financial Boards, Health Department, and the Ministry of Health, the staffsstill could learn the steps and input method manually and independently.

"So far, we learned independently the manual user of ASPAKinputdata through the internet. We also learned from the guidebook of input data in simda BMD. We consulted or called BKD, the Ministry of Health, or Provincial Health Department when encountered difficulties." (M, 33 years, staff in charge at planing and report section of Waras Wiris hospital).

The statement is in line with the statement from another informant:

"We expected to be invited at the socialization and training of ASPAK inthe 
Provincial Health Department or at socialization and training in BKD." (BR, 43 years, goods treasurer of Waras Wiris hospital)

The statement is in line with the statement of other informants :

"The previous stafftaught me to learn and practice independently and call BKD if there were difficulties." (A, 26 years, warehouse section in Simo hospital).

The input data of the three Regional Public Hospitals in Boyolali Regency until 2019 was already presented on both applications. Manual inventory and labeling had been carried out to all assets including (function and condition check) worthiness check, renewal of rooms inventory, maintenance and calibration schedule, and decommissioning. The Reconciliatory Reportwas already issued by the Regional Financial Board

"After an item is received by the inventory department it would go through operability checking, labeling, renewal of rooms inventory list, maintenance and calibration scheduling before the head of the department receives it legally" (M, 50 years, goods treasurer of Pandanarang hospital).

The statement is in line with the statement from another informant:

"The data input of simda in Waras Wiris Hospital for the year 2019 was issuedby the legal clearance in form of $B A$ rekon from BKD." (BR, 44 years, goods treasurer Waras Wiris hospital).

During the document observation on the ASPAK application, these three hospitals were all still undergoing assets input process from the year of 2019. An inspection showed that the hospitals scored between $45-63 \%$ on the inventory of infrastructure and medical equipment. Among the three hospitals, Pandanarang Hospital was regarded as the most sophisticated because of the mandatory serial number input for every appliance. This prevented the possibility of an appliance being used in two different rooms and helping to meet the calibration requirements of the appliance with great cost because the new menu in ASPAK was directly connected to the Medical Resources Safety Section/ BPFK so the calibration obligation appeared on medical devices. The other two hospitals were on progress to attain the same level as Pandanarang Hospitalbecause those hospitals were still focusing on resource and infrastructure development.

"In 2019, we had not been able to carry out all the required calibration obligations"(DS, 42 years, Head of Medical Support Section of Waras Wiris Hospital).

The statement is in line with the statement from another informant:

"The calibration duty should be carried out as possible. The main obstacle is matching the schedule between the hospital and the implementer of the calibration". (DAP, 44 years old, staffin charge of ASPAK of Pandanarang Hospital)

Based on the input process in the dual asset applications, almost all the subjects of the study stated that ASPAK was easier than simda BMD.

"The input process in Simda BMD must be prepared thoroughly before it transferred to $B K D$, because the input could only be performed in BKD so if there is incomplete data, it must be rechecked to avoid inefficient data input”. (EE, 40 years, warehouse section of Waras Wiris hospital).

The statement is in line with another informant:

"We rarely got the training of ASPAK. We had to learned independently. The socialization was conducted at an inappropriate time whereas the menu in 
ASPAK often changed."(BR, 43 years, treasurer of goods of Waras Wiris hospital)

The result of the interview of the staffin charge.

"We have divided the tasks and responsibilities in managing the asset to be more focused, obtain better results and prevent missed obligation. However, it should be supported by serious personnel in performing the responsibilities." $(\mathrm{M}, 50$ years, the goods treasurer of Pandanarang hospital).

The statement is in line with the statement given by another informant:

"The steps in managing the asset were often overdue because we had other tasks as hygene and sanitation staff, infrastructure maintenance staff, and the other tasks."(GBW, 38 years, goods treasurer of Simo hospital)

Both of these applications were resourceful and effective in terms of asset inventory and prevent any loss or discrepancy of inventory from the manual listing. This system had been integrated into simda BMD. Furthermore, the planning, budgeting, purchase, breakage, and decommissioning steps were also made effective through this continuous integration. The asset belonged to the hospitals could also be tracked through the integration between simda BMD and simda finance. The final ASPAK could be able to rate the hospital in terms of its standard, regulated service on the relation with its operating permit, accreditation, credential, and yearly budgeting

"This application is very helpful compared to manuallisting in which the risk of errors is greater" (S, 55 years, warehouse section Pandanarang Hospital).

The statement is in line with the statement by another informant: "The data input in the ASPAK, would show the efforts of the hospital to occupy the standard. It would affect the next year's plan, especially DAK." (S, 44 years, Head of Administration Subdivision at Simo Hospital)

The prior data from Simda BMD was used as the guiding data, the input for these two applications wascarried out separately, with different methods, and different results. It was expected that these two applications could be made integrated with only once the data input required. At that moment, RSUD Pandanarang was developing a liaison application which was expected to be able to link the two applications, to discard redundant input method, and to accommodate the entire asset management on the parts of asset listing, maintenance schedule, and automatic calibration to prevent any delay, damage, and loss. This same step on the application of information technology had also been initiated in RSUD WarasWiris.

"At that time, Regional Public Hospital Pandanarang was trying to compile a liaison application which was being drafted by the hospital IT team, thus the input process in the two applications and other asset management processes were more easily coordinated". (DAP, 44 years, staff in charge of ASPAK of Pandanarang hospital).

The statement is in line with the statement from another informant:

"Pandanarang Hospital did not use manual method to remind the maintenance and calibration schedules but the hospital used technology that utilized social media". ( $M, 50$ years, goods treasurer of Pandanarang Regional Hospital).

The statement was in line with the statement from another informant:

"Waras Wiris hospital had conducted coordination between the Technology, and Informatic (IT) team, hospital management and asset administrator to utilize 
information technology to help the assets management". (BR, 43 years, goods treasurer of Waras Wiris hospital).

Hospital Management played an essential role in the process of asset management in a Hospital such as planning, budgeting, procurement, distribution, maintenance, inventory, and proposed destruction. Therefore, all the process could be performed on time and in appropriate conditions. Good asset management was expected to provide the satisfaction of the patients and decrease complaint and referral rates. Regional Financial Board had roles in providing training, guiding, and monitoring to the staff to improve the assets management. The role of the Health Departement in monitoring the ASPAK was obviousto check the data with conditions on the site.

"Management hasroles in planning, budgeting, monitoring, and assisting so that everything was carried out on time and correctly." (S, 44 years, Head of Administration Subdivision of Simo hospital).

The statement is in line with the statement from another informant:

"BKD and DKK were expcetd to have a major role in providing training and guidance." (BR, 43 years, treasurer of Waras Wiris Hospital).

The statement is in line with the statement from another informant:

"The roles of Hospital management are manager, controller, and persons in charge of the Hospital operational." (DS, 42 years, Head of Medical Support of Waras Wiris Hospital).

\section{DISCUSSION}

The result of the study presented that the three hospitals had used dual health assets aplications byThe Ministry of Internal Affairs developed by the State Development Audit AgencynamelyRegional Management
Information System of Regional Property (Simda BMD) and the application by The Ministry of Health namely Application of Infrastructure and Medical Devices (ASPAK). It is in line with the mandate of the Ministry of Home Affairs Regulation Number 19 of 2016 concerning Guidelines for the Management of Regional Property and the Ministry of Health Regulation number 31 of 2018 concerning Application of Infrastructure Facilities and Medical Devices.

The result showed that the good management of health assets was expected to increase patient satisfaction and reduce complaints and referral rates. The result of this study is in line with the study conducted by Hod (2016) that the efficiency in the service sector was one of the factorsthat affect the reduction of referral rates and global economic development. Health care services, especially hospitals, required intensive resource management. An increase in efficiency in that sectioncould increase its economic potency if it was managed effectively.

Pross et al. (2018) argued that health asset management in every hospital had different levels of needs with different environmental, patient characteristics, and medical conditions. Therefore, this required an optimal balance between health care service/quality medical service and the efficency of infrastructure systems. According to Nabyonga-Orem and Mijumbi, less accurate data could cause the patients to get a lack of information. The accurate information of the data could optimally improve health care service, especially when the patients required referrals. The performance improvement of health asset management became one of the keys to synchronize the data. Another benefit was the data could be used by the policy makers to improve the public service. The data accu- 
racy and timeliness was one of the prerequisites for the good quality of asset management.

Drobac et al. (2013) stated that the availability of information did not guarantee an effective implementation without proper decision making or treatment policy. The quality of the service was affected by several factors namely income, education level, and visitation to public health centers. The factors which influenced the patients' satisfaction level were income, education, frequency of visits, and service quality. WHO (2004) cited atInnocent et al. (2016) argued that problems related to health service occurred due to inadequate monitoring and evaluation, incomplete data, and tardy data transmission from the filling and report stage. Therefore, an effectivemechanism that suits the needs of each asset management was required. Complete and accurate data were essential especially in thecertain service levelwhich function was to submit to a higher level.

The data from health application should be used to analyze and resolve the health and service problems and priority problems which required optimal treatment so it could provide quality health service. Based on the result of the study, there were two conclusions. First, the staff who in charge in managing the system and asset management require training to improve the capability. Second, a system is also required to link the two applications to provide more efficient input system and create interoperability.

\section{AUTHOR CONTRIBUTION}

Yunita Rusdiyanti as the main researcher had responsibilities to collect and process the data. Bhisma Murti examined the concept draft and the methodology of the study. Didik Gunawan Tamtomo reviewed the study.

\section{CONFLICT OF INTEREST}

This study did not have any conflict of interest.

\section{FUNDING AND SPONSORSHIP}

This study used a personal fund from the researcher.

\section{ACKNOWLEDGEMENT}

We give the gratitude to Didik Gunawan Tamtomo and Bhisma Murti who have analyzed and reviewed this study. We also give the best gratitude to the hospitals that have been cooperative and all the informants who have participated as the informants of this study.

\section{REFERENCE}

Antoh A (2017). Pengaruh manajemen aset dalam optimalisasi aset tetap (tanah dan bangunan) Pemerintah Daerah (studi di Kabupaten Paniai). ECOMBISMA, 1(2): 37-47. Retrieved from www.jurnal. manucen.ac.id.

BryantKA, Harris AD, Gould CV, Humphreys E, Lundstrom $\mathrm{T}$, et al. (2016). Necessary infrastructure of infection prevention and healthcare epidemiology programs: A review. Infect Cont Hosp Ep, 37(4): 371-380. doi: 10.1017/ice.2015.333.

DrobacPC, Basinga P, Condo J, Farmer PE, Hamonet al (2013).Comprehensive and integrated district health systems strengthening: The Rwanda Population Health Implementation and Training (PHIT) Partnership. BMC Health ServRes, 13(2): 55. doi: 10.1186/1472-6963-13-S2-S5.

Harmein N, Nasution E, Absah Y (2015). Pengaruh manajemen aset terhadap optimalisasi aset rumah sakit jiwa Daerah Provinsi Sumatera Utara. JEPI, 18(1): 10-18.Retrieved from http://repository.usu.ac.id/bitstream- 
/handle/123456789/43647/erlini\%2oharmein\%2oyeni.pdf;sequence $=1$.

Hidayati H (2014). Standar pelayanan kesehatan pasien IGD di rumah sakit umum abdul wahab sjahranie Samarinda. JDG, 3(2): 653-665. Retrieved from ejournal.an.fisip-unmul.org.

HodR, Maimon O, Zimlichman E (2016). The relationships between hospital service quality and operational efficiency: An alternative model.Health Economics \& Outcome Research, 2(3). doi: 10.4172/2471-268x.1000119.

Innocent K, Anguyo R, Katangole SP, Govule (2016). Quality and use of routine healthcare data in selected districts. Int JPublic Health Res, 4(2):513. Retrieved from https://hdl.handle.net/20.500.12280/419.

Nabyonga-Orem J, Mijumbi R (2015). Evidence for informing health policy development in low-income countries
(LICs): Perspectives of policy actors in Uganda. Int $\mathrm{J}$ Health Policy Manag, 4(5): 285-293. doi: 10.15171/ijhpm.2015.52 .

Permatasari A (2014). Aset manajemen rumah sakit berbasis web system. UNISSULA, 10(1): 70-75. Retrieved from https://www.neliti.com/id/publications/170003/aset-manajemenrumah-sakit-berbasis-web-system.

Pross C, Strumann C, Geissler A, Herwartz H, Klien N (2018). Quality and resource efficiency in hospital service provision: A geoadditive stochastic frontier analysis of stroke quality of care in Germany. PLoS ONE, 13(9): 1-30. doi: 10.1371/journal.pone.0203017.

WHO (2018). Delivering quality health services, World Health Organization, World Bank Group, OECD. Retrieved from http://apps.who.int/bookorders. 